\title{
Technical Note: A simple method for vaterite precipitation for isotopic studies: implications for bulk and clumped isotope analysis
}

\author{
T. Kluge ${ }^{1,2}$ and C. M. John ${ }^{1}$ \\ ${ }^{1}$ Department of Earth Science and Engineering and Qatar Carbonate and Carbon Storage Research Centre, \\ Imperial College London, Prince Consort Road, London, SW7 2BP, UK \\ ${ }^{2}$ now at: Institut für Umweltphysik, Universität Heidelberg, Im Neuenheimer Feld 229, 69120 Heidelberg, Germany \\ Correspondence to: T. Kluge (tobias.kluge@ @iup.uni-heidelberg.de)
}

Received: 10 November 2014 - Published in Biogeosciences Discuss.: 12 December 2014

Revised: 9 March 2015 - Accepted: 6 May 2015 - Published: 3 June 2015

\begin{abstract}
Calcium carbonate $\left(\mathrm{CaCO}_{3}\right)$ plays an important role in the natural environment as a major constituent of the skeleton and supporting structure of marine life and has high economic importance as an additive in food, chemicals and medical products. Anhydrous $\mathrm{CaCO}_{3}$ occurs in the three different polymorphs calcite, aragonite and vaterite, whereof calcite is the most abundant and best characterized mineral. In contrast, little is known about the rare polymorph vaterite, in particular with regard to the oxygen isotope fractionation between $\mathrm{H}_{2} \mathrm{O}$ and the mineral.

Synthetic precipitation of vaterite in the laboratory typically involves rapid processes and isotopic non-equilibrium, which excludes isotope studies focused on the characterization of vaterite under equilibrium conditions. Here, we used a new experimental approach that enables vaterite mineral formation from an isotopically equilibrated solution. The solution consists of a $\sim 0.007 \mathrm{~mol} \mathrm{~L}^{-1} \mathrm{CaCO}_{3}$ solution that is saturated with $\mathrm{NaCl}$ at room temperature (up to $6.4 \mathrm{~mol} \mathrm{~L}^{-1}$ ). Vaterite precipitated as single phase or major phase $(\geq 94 \%)$ in experiments performed between 23 and $91{ }^{\circ} \mathrm{C}$. Only at $80^{\circ} \mathrm{C}$ was vaterite a minor phase with a relative abundance of $27 \%$. The high mineral yield per experiment of up to $235 \mathrm{mg}$ relative to the initially dissolved $\mathrm{CaCO}_{3}$ amount of on average $360 \mathrm{mg}$ enables an investigation of the oxygen isotope fractionation between the mineral and water, and the determination of clumped isotope values in vaterite.
\end{abstract}

\section{Introduction}

Vaterite is the least known polymorph of calcium carbonate and was first described by Vater (Vater, 1893). In the 1920s and 1930s, the nature and crystallographic structure of vaterite was still questioned and the occurrence of a third polymorph of $\mathrm{CaCO}_{3}$ was disputed amongst various groups (Johnston et al., 1916; Spangenberg, 1921; Heide, 1924; Rinne, 1924; Gibson et al., 1925). In the following decades, work mainly focused on the structure of vaterite (e.g. McConnell, 1960; Kamhi, 1963; Meyer, 1969; Mann et al., 1991; Wang and Becker, 2009), which continues to be a source of surprises today (Kabalah-Amitai et al., 2013). Vaterite has a major hexagonal structure (von Olshausen, 1925) and appears in different morphologies such as spherulitic aggregates (Han et al., 2006; Nebel and Epple, 2008; Mori et al., 2009; Hu et al., 2012) or hexagonal plates (e.g. Johnston et al., 1916; Kamhi, 1963; Dupont et al., 1997; Xu et al., 2006; Kawano et al., 2009).

Vaterite occurrence in nature is more widespread than generally assumed. It was first observed in gastropods (Mayer and Weineck, 1932), but later studies also discovered vaterite to be related to oil field drilling (Friedman and Schultz, 1994) and to be found in Portland cement (Friedman and Schultz, 1994) and as stones in the urinary system (Prien and Frondel, 1947; Sutor and Wooley, 1968). Vaterite has not been found in the geologic record and is therefore suspected to be metastable. The observation of vaterite in biogenic systems (Mayer and Weineck, 1932; Spann et al., 2010; Nehrke et al., 2012; Kabalah-Amitai et al., 2013) gives some constraints on 
its stability, which can be on the order of years (Lowenstamm and Abbott, 1975), but not geological ages.

The natural occurrence of vaterite and its potential economic use due to its large specific surfaces and high porosity (Mori et al., 2009) warrants a precise investigation of this mineral. So far, most laboratory experiments have been designed to precipitate relatively large single crystals of vaterite for X-ray analysis that focused on the crystal structure (e.g. Kamhi, 1963). Vaterite precipitation experiments generally used either mixtures of several solutions such as $\mathrm{K}_{2} \mathrm{CO}_{3}, \mathrm{Na}_{2} \mathrm{CO}_{3}$ and $\mathrm{CaCl}_{2}$ (Kamhi, 1963; Easton and Claugher, 1986; Han et al., 2006; Nebel and Epple, 2008) or $\mathrm{CaNO}_{3}$ (Davies et al., 1978), sometimes with added surfactants (Mann et al., 1991; Dupont et al., 1997; Mori et al., 2009), or additional organic substrates (Falini et al., 1996; Xu et al., 2006; Kirboga and Oner, 2013). These experiments provided crystals with sizes between a few hundred nanometres and a few micrometres and were mostly restricted to the temperature range of $25-60^{\circ} \mathrm{C}$.

As vaterite is a relevant mineral in biogenic systems (Lowenstamm and Abbott, 1975; Pouget et al., 2009; Spann et al., 2010; Nehrke et al., 2012) it may provide new insights into isotope fractionation during biological carbonate formation. Vaterite has been proposed as a potential precursor phase in biogenic $\mathrm{CaCO}_{3}$ precipitation, later transforming into aragonite or calcite (e.g. Jacob et al., 2008). Depending on conditions prevailing during the vaterite-aragonite or vaterite-calcite transformation, the original isotope signature may be inherited in the final, stable $\mathrm{CaCO}_{3}$ phase. In order to be able to use isotopic tools (for instance, to reconstruct environmental conditions or palaeoclimate) on biogenic carbonate with vaterite precursors or remaining vateritic components, knowledge of the fractionation factor between vaterite and water and the clumped isotope $\Delta_{47}-T$ relationship of vaterite is required. However, so far little is known about the oxygen isotope fractionation between dissolved inorganic carbon and vaterite and, in particular, the clumped isotope $\Delta_{47}-T$ relationship of vaterite. Whereas vaterite was reported in a few stable isotope studies aiming at determining the oxygen isotope fractionation factor in the system $\mathrm{CaCO}_{3}-\mathrm{H}_{2} \mathrm{O}$ (e.g. Kim and O'Neil, 1997), it rarely occurred as a pure phase and thus did not allow for a precise study focused on vaterite. Based on the limited data available, Tarutani et al. (1969) suggested vaterite to be enriched in ${ }^{18} \mathrm{O}$ by $+0.5 \%$ relative to calcite. Kim and O'Neil (1997) obtained a similar value of $+0.6 \%$ with respect to calcite. Both studies were limited to either one $\left(25^{\circ} \mathrm{C}\right)$ or two temperatures $\left(25,40^{\circ} \mathrm{C}\right)$, and a more comprehensive study is still lacking. In addition, the clumped isotope $\Delta_{47}-T$ relationship of vaterite has not been assessed so far, but could give new insights into the effect of polymorphism on isotope ratios or mineral growth-related isotope fractionation.

In this study we present a simple method that allows vaterite precipitation over a wide temperature range (at least between 20 and $91{ }^{\circ} \mathrm{C}$ ) and that provides large quantities of the mineral, enabling for example the investigation of the oxygen isotope fractionation factor between vaterite and $\mathrm{H}_{2} \mathrm{O}$, and the $\Delta_{47}-T$ relationship of vaterite.

\section{Experimental setup}

The precipitating solution was prepared by dissolving highpurity $\mathrm{CaCO}_{3}$ (Merck Suprapur, 99.95\%) in de-ionized water. Light microscopy indicates that this $\mathrm{CaCO}_{3}$ consists of calcite. The water was initially taken from the local water supply, purified with a reverse osmosis technique and finally de-ionized with an Ultrapure ${ }^{\mathrm{TM}}$ system with an output quality of $18 \mathrm{M} \Omega \mathrm{cm}$. Trace components of the $\mathrm{CaCO}_{3}$ used to prepare the solution are strontium $(\leq 100 \mathrm{ppm})$, rubidium $(\leq 20 \mathrm{ppm})$, sulfate $(\leq 20 \mathrm{ppm})$, and phosphate $(\leq 10 \mathrm{ppm})$.

About $370 \mathrm{mg}$ of $\mathrm{CaCO}_{3}$ was dissolved in $\sim 500 \mathrm{~mL}$ deionized water at room temperature per experiment. The water was acidified by the purging of $\mathrm{CO}_{2}$ tank gas (normal grade, BOC UK) through the solution. The solution was filtered after $3 \mathrm{~h}$ through a double layer of Whatman ${ }^{\circledR}$ filter paper (grade 1, corresponding to $11 \mu \mathrm{m}$ filtration size) to remove undissolved $\mathrm{CaCO}_{3}$ crystals. Optical inspection of the filtered water via light reflectance confirmed no large crystals to have bypassed the filtration stage. The dissolution step appeared to be quantitative as no $\mathrm{CaCO}_{3}$ was visibly retained on the filter paper.

The filtered $\mathrm{CaCO}_{3}$ solution was then thermally and isotopically equilibrated at a set temperature in a temperaturecontrolled water bath (a sketch of the experimental setup is depicted in Fig. 1). The experimental temperatures ranged from 23 to $91^{\circ} \mathrm{C}$. The solution was enclosed in a $500 \mathrm{~mL}$ Erlenmeyer flask with a rubber stopper. The rubber stopper contained two feed-throughs for tubes that were used to maintain a constant gas flow through the solution. $\mathrm{Hu}-$ midified and thermally equilibrated $\mathrm{CO}_{2}$ gas (same temperature as the solution) was passed through the $\mathrm{CaCO}_{3}$ solution (Table 1) at a rate of $\sim 0.03-0.1 \mathrm{~mL} \mathrm{~s}^{-1}$ to prevent carbonate precipitation before complete isotopic equilibrium was achieved. The $\mathrm{CO}_{2}$ gas was humidified and adjusted to the experimental temperature by bubbling it slowly through an Erlenmeyer flask filled with de-ionized water and contained in the temperature-controlled water bath. The equilibration period varied between $3 \mathrm{~h}$ at $91^{\circ} \mathrm{C}$ and $23 \mathrm{~h}$ at $23^{\circ} \mathrm{C}$. pH values during equilibration are below $\mathrm{pH} 6$ due to the continuous $\mathrm{CO}_{2}$ flux.

After equilibration, $\mathrm{NaCl}$ was added, reaching concentrations between 4.2 and $6.4 \mathrm{~mol} \mathrm{~L}^{-1}$ (Table 1). The added $\mathrm{NaCl}$ (Sigma Aldrich ${ }^{\circledR}$ ) has a purity of $\geq 99 \%$ and contains minor traces of sulfates $(\leq 200 \mathrm{ppm})$, alkaline earth metals $(\leq 100 \mathrm{ppm})$ and bromides $(\leq 100 \mathrm{ppm})$. Carbonate precipitation was induced by slowly bubbling $\mathrm{N}_{2}$ tank gas (BOC $\mathrm{UK}$, normal grade) through the solution. The $\mathrm{N}_{2}$ gas was humidified and adjusted to the experiment temperature using the same procedure as for the $\mathrm{CO}_{2}$ gas. The bubbling rate 

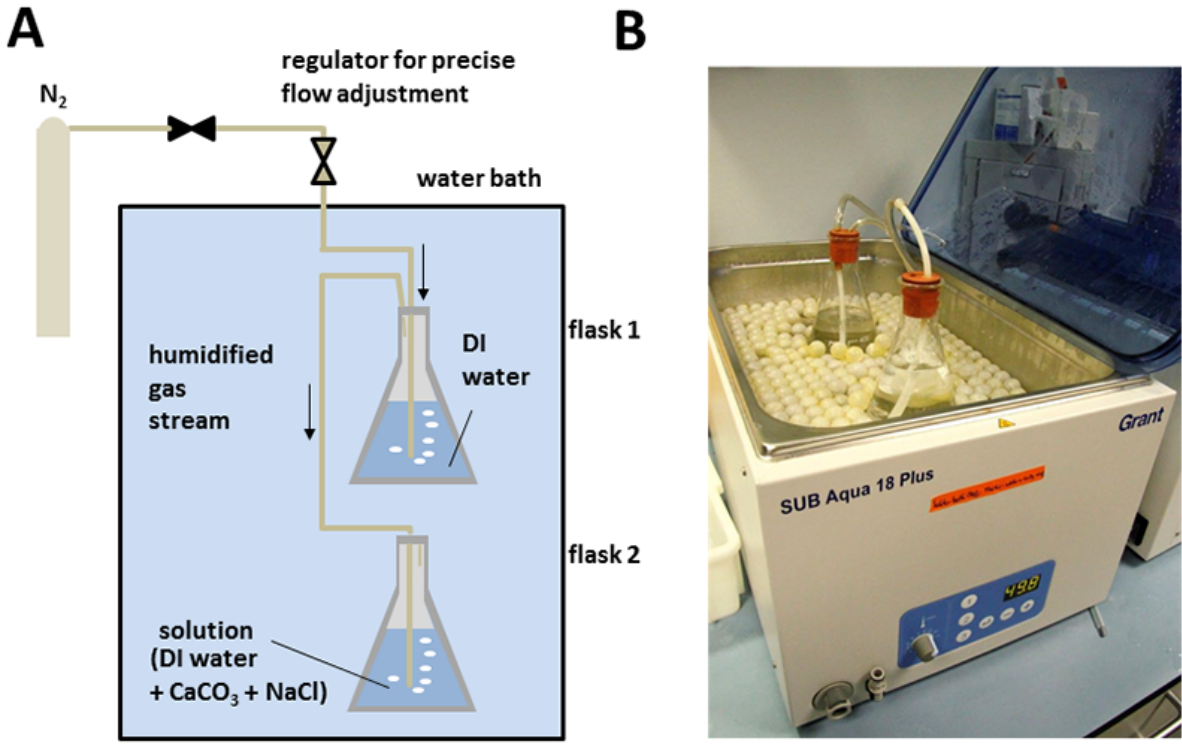

Figure 1. Sketch (a) and photograph (b) of the experimental setup used to precipitate vaterite. In the first step, $\mathrm{CaCO}_{3}$ is dissolved in de-ionized (DI) water (outside the water bath), which is filtered after $>3 \mathrm{~h}$ to remove any undissolved components. The solution is then transferred to a temperature-controlled water bath for thermal and isotopic equilibration (flask 2 in a). $\mathrm{NaCl}$ is added after the equilibration step. Mineral formation is induced by slow bubbling of $\mathrm{N}_{2}$ through the solution. The gas stream through the solution in flask 2 is humidified by passing it beforehand through another flask filled with de-ionized water (flask 1).

Table 1. Experimental conditions during laboratory precipitation of $\mathrm{CaCO}_{3}$ (see Sect. 2).

\begin{tabular}{lccccc}
\hline $\begin{array}{l}\text { Experiment } \\
\text { no. }\end{array}$ & $\begin{array}{c}T \\
\left({ }^{\circ} \mathrm{C}\right)\end{array}$ & $\begin{array}{c}\mathrm{CaCO}_{3, \text { dissolved }} \\
\left(\mathrm{g} \mathrm{L}^{-1}\right)\end{array}$ & $\begin{array}{c}\mathrm{NaCl} \text { added } \\
\left(\mathrm{g} \mathrm{L}^{-1}\right)\end{array}$ & $\begin{array}{c}\text { Equilibration } \\
(\mathrm{h})\end{array}$ & $\begin{array}{c}\text { Precipitation } \\
(\mathrm{h})\end{array}$ \\
\hline NA-1 & $23.5 \pm 0.5$ & 0.68 & 250 & 23 & 451 \\
NA-3* & $37.5 \pm 0.5$ & 0.70 & 260 & 21 & 72 \\
NA-4 & $37.5 \pm 0.5$ & 0.74 & 244 & 14 & 341 \\
NA-5 & $49.6 \pm 0.5$ & 0.70 & 375 & 16 & 143 \\
NA-6 & $49.6 \pm 0.5$ & 0.80 & 262 & 17 & 573 \\
NA-7 & $69.9 \pm 0.5$ & 0.70 & 325 & 3 & 69 \\
NA-8 & $79.9 \pm 0.5$ & 0.78 & 280 & 3 & 47 \\
NA-9 & $91.0 \pm 0.5$ & 0.70 & 260 & 3 & 42 \\
\hline
\end{tabular}

* NA-2 differed in the experimental conditions and is therefore omitted.

was set to about 1 bubble per second $\left(\sim 0.03 \mathrm{~mL} \mathrm{~s}^{-1}\right)$. The gas stream was humidified to prevent water evaporation and a potential change in the solution $\delta^{18} \mathrm{O}$ value over time. Minerals always formed on the bottom or the side wall of the Erlenmeyer flask. No crystals were observed on the surface of the solution. After 2-19 days, the solution was passed through a double layer of Whatman ${ }^{\circledR}$ filter paper (grade 1 with a pore size of $11 \mu \mathrm{m}$ ). Crystals on the glass walls were loosened by a thin PVC plastic tube and flushed out with de-ionized water. The precipitated minerals were air-dried at room temperature before microscopic and XRD (X-ray diffraction) analysis was conducted.

\section{Samples}

\subsection{Mineral description, microscopy and SEM}

Depending on the experiment, temperature and duration, between 5 and $235 \mathrm{mg} \mathrm{CaCO}_{3}$ was precipitated (Tables 1, 2). Low carbonate recovery $<20 \mathrm{mg}$ is linked to short experiment duration (3-6 days) at lower temperatures $\left(<70^{\circ} \mathrm{C}\right.$, Table 2). In contrast, experiments with a longer duration of 14 24 days at temperatures $\leq 50^{\circ} \mathrm{C}$ yielded on average $135 \mathrm{mg}$. At $80-91{ }^{\circ} \mathrm{C}$ it was sufficient to allow 2 days for mineral precipitation to obtain $80-90 \mathrm{mg}$ of calcite. Note that in all experiments the initially dissolved amount of calcite was similar at about $360( \pm 20) \mathrm{mg}$ in $500 \mathrm{~mL}$ of de-ionized water (Table 1). 
Table 2. Mineralogical and isotopic results of the vaterite precipitation experiments. The mineralogy was determined by XRD analysis (Sect. 3.2). The $n$ values give the number of replicates measured for isotopic analysis. The $\Delta_{47}$ value is given in the absolute reference frame of Dennis et al. (2011) and is corrected for the acid digestion reaction.

\begin{tabular}{|c|c|c|c|c|c|c|c|}
\hline $\begin{array}{l}\text { Experiment } \\
\text { no. }\end{array}$ & $\begin{array}{c}T \\
\left({ }^{\circ} \mathrm{C}\right)\end{array}$ & $\begin{array}{c}\mathrm{CaCO}_{3, \text { precipitated }} \\
\text { (mg) }\end{array}$ & $\begin{array}{c}\delta^{18} \mathrm{O} \\
(\% o)\end{array}$ & $\begin{array}{l}\delta^{13} \mathrm{C} \\
(\% o)\end{array}$ & $\begin{array}{l}\Delta_{47} \\
(\% o)\end{array}$ & $\begin{array}{c}n \\
(-)\end{array}$ & Mineralogy \\
\hline NA-1 & $23.5 \pm 0.5$ & 120 & $-8.57 \pm 0.16$ & $-18.21 \pm 0.06$ & $0.689 \pm 0.003$ & 3 & vaterite \\
\hline NA-3* & $37.5 \pm 0.5$ & 5 & $-11.29 \pm 0.20$ & $-20.39 \pm 0.10$ & $0.639 \pm 0.020$ & 1 & $\begin{array}{l}\text { vaterite }(95 \%) \text {, } \\
\text { calcite }(5 \%)\end{array}$ \\
\hline NA-4 & $37.5 \pm 0.5$ & 50 & $-13.30 \pm 0.37$ & $-26.06 \pm 0.18$ & $0.672 \pm 0.027$ & 3 & $\begin{array}{l}\text { vaterite }(>95 \%) \text {, } \\
\text { rest: calcite }\end{array}$ \\
\hline NA-5 & $49.6 \pm 0.5$ & 15 & $-13.85 \pm 0.26$ & $-21.39 \pm 0.03$ & $0.605 \pm 0.005$ & 2 & vaterite \\
\hline NA-6 & $49.6 \pm 0.5$ & 235 & $-15.06 \pm 0.22$ & $-25.26 \pm 0.17$ & $0.634 \pm 0.008$ & 3 & vaterite \\
\hline NA-7 & $69.9 \pm 0.5$ & 15 & $-16.92 \pm 0.15$ & $-21.71 \pm 0.03$ & $0.577 \pm 0.010$ & 3 & vaterite \\
\hline NA-8 & $79.9 \pm 0.5$ & 80 & $-17.54 \pm 0.03$ & $-25.86 \pm 0.10$ & $0.553 \pm 0.018$ & 3 & $\begin{array}{l}\text { calcite }(49 \%), \\
\text { aragonite }(24 \%), \\
\text { vaterite }(27 \%)\end{array}$ \\
\hline NA-9 & $91.0 \pm 0.5$ & 90 & $-19.21 \pm 0.15$ & $-25.00 \pm 0.16$ & $0.545 \pm 0.005$ & 5 & $\begin{array}{l}\text { vaterite }(94 \%), \\
\text { aragonite }(6 \%) \text {, } \\
\text { calcite }(<1 \%)\end{array}$ \\
\hline
\end{tabular}

* NA-2 differed in the experimental conditions and is therefore omitted.
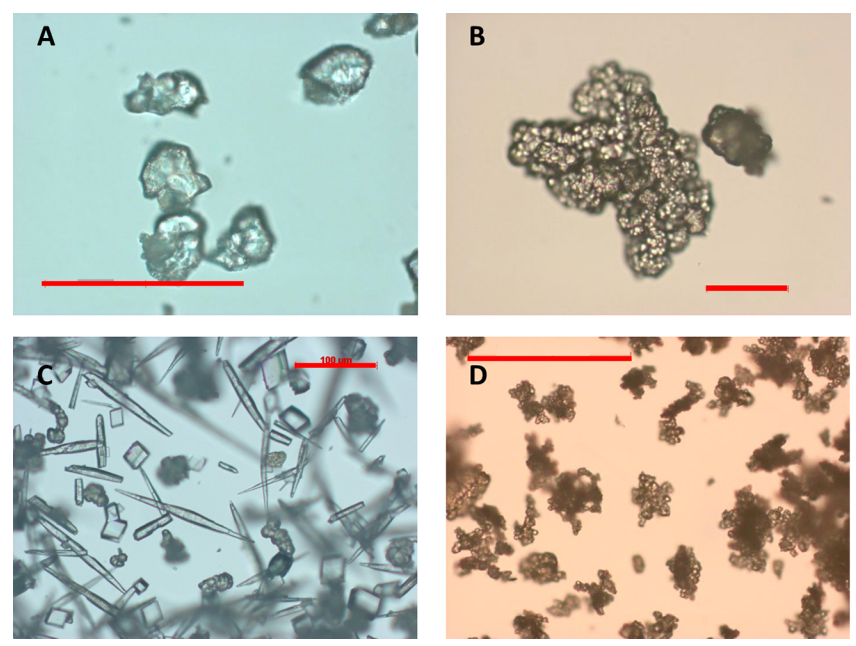

Figure 2. Photomicrographs of $\mathrm{CaCO}_{3}$ minerals precipitated in the laboratory experiment. Scale bar is $100 \mu \mathrm{m}$ in (a)-(c) and $200 \mu \mathrm{m}$ in (d). Vaterite crystals formed at $50{ }^{\circ} \mathrm{C}$ in experiment NA-6 (a), at $70^{\circ} \mathrm{C}(\mathbf{b})$ and at $91^{\circ} \mathrm{C}(\mathbf{d})$. At $80^{\circ} \mathrm{C}$ a mixture of aragonite, calcite and vaterite was precipitated (c).

Vaterite can be distinguished from other $\mathrm{CaCO}_{3}$ polymorphs by its morphology. Calcite rhombohedra and aragonite needles can be recognized by light microscopy (e.g. Fig. 2c). Vaterite crystals can be similar in size but are more irregular and show a spherulitic shape (Figs. 3, 4). Inspection of large vaterite crystals under normal and polarized light reveals a complex growth history. Various globular segments of 50-100 $\mu \mathrm{m}$ with an internal spherulitic growth pattern coalesce into one larger crystal (Fig. 4). Vaterite crystals

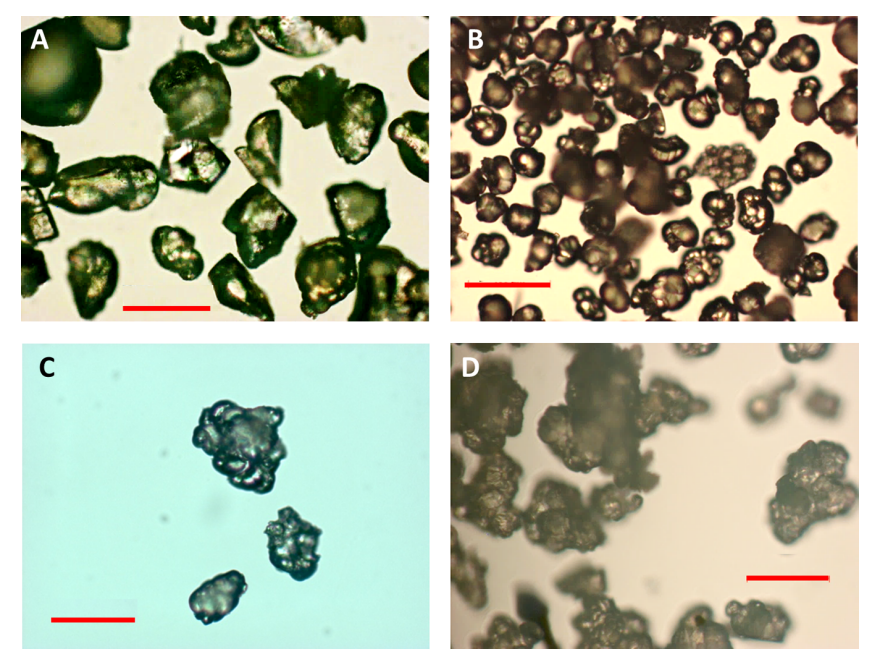

Figure 3. Photomicrographs of $\mathrm{CaCO}_{3}$ minerals precipitated in the laboratory experiments. Scale bar is $100 \mu \mathrm{m}$. Vaterite crystals formed at $23{ }^{\circ} \mathrm{C}$ (a), at $37^{\circ} \mathrm{C}$ in experiment NA-3 (b) and NA-4 (c), and at $50^{\circ} \mathrm{C}$ in NA-5 (d).

showed a typical size of $50 \mu \mathrm{m}$ (Figs. 2, 3, 4), whereas in a few experiments, crystals of up to $500 \mu \mathrm{m}$ were observed. Experiments at 70 and $91{ }^{\circ} \mathrm{C}$ also resulted in vaterite crystals in the $50 \mu \mathrm{m}$ size range; however, these are composed of many small $(\sim 10 \mu \mathrm{m})$ globular sub-segments. A peculiarity of vaterite crystals precipitated at $23^{\circ} \mathrm{C}$ is the combination of rounded, spherical shapes with sharp angular forms (Fig. 3a). Together with the larger crystals sizes observed at this temperature; this points towards slower mineral growth. All minerals of this study were investigated with XRD in ad- 

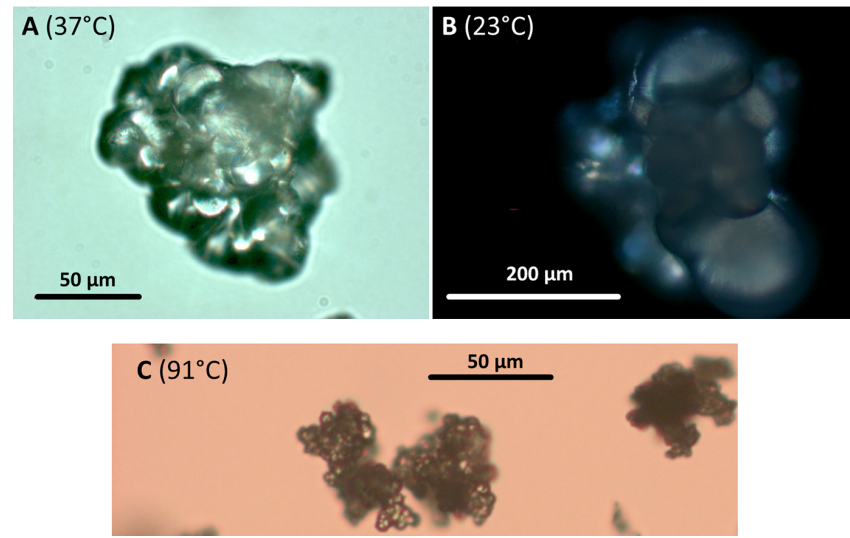

Figure 4. Close-up photomicrographs of vaterite minerals. Scale bar is $50 \mu \mathrm{m}$ in (a) and (c), and $200 \mu \mathrm{m}$ in (b). Panel (b) shows a vaterite crystal using polarized light.

dition to optical microscopy. Note that optical microscopy alone may be ambiguous and should be complemented by additional methods (e.g. XRD).

Scanning electron microscope (SEM) images were made at the Institute of Earth Sciences at Heidelberg University to investigate the morphology in more detail. The scanning electron microscope LEO 440 was used for imaging. It has a tungsten cathode, was operated at an accelerating voltage of $20 \mathrm{kV}$, and enables a minimal resolution of ca. $5 \mathrm{~nm}$. Samples were sputtered with a thin gold layer for imaging and with carbon for elemental analysis. A summary with characteristic vaterite aggregates is shown in Fig. 5. The size of individual grains that make up the vaterite aggregates was investigated using SEM images (Figs. 5, 6). The grain size decreases with increasing temperature, from about $100 \mu \mathrm{m}$ at $23^{\circ} \mathrm{C}, 10$ to $20 \mu \mathrm{m}$ at $50^{\circ} \mathrm{C}$, to $<10 \mu \mathrm{m}$ at $91^{\circ} \mathrm{C}$. The relatively large grains detected at $23^{\circ} \mathrm{C}$ are internally composed of $\sim 2 \mu \mathrm{m}$ long elongated fibrous crystallites (Fig. 6a). The smallest grains observed at $91^{\circ} \mathrm{C}$ are of a similar size of a few micrometres. Sub-micrometre-sized crystallites and framboidal aggregates (e.g. Nehrke and Van Cappellen, 2006) were not observed. The minerals show a radial growth pattern from a central nucleus leading to spherical conglomerate particles (Fig. 5a). The spherical shape is still dominant at $50^{\circ} \mathrm{C}$ (Fig. 5b); however, it changes to the growth of flat platelets at $91^{\circ} \mathrm{C}$ (Fig. 5c). The radiating growth pattern at $91^{\circ} \mathrm{C}$ is restricted to two dimensions with a tree-like branching structure characteristic for diffusion-controlled dentritic crystallization (Fig. 5d).

Additional elemental analyses on carbon-sputtered vaterite grains using energy-dispersive X-ray spectroscopy (EDS) at the SEM system at Heidelberg University revealed minor traces of sodium and chloride to be occasionally incorporated in the vaterite mineral. Quantitative analysis was not attempted due to the very sporadic and dispersed occurrence of the sodium chloride crystals.
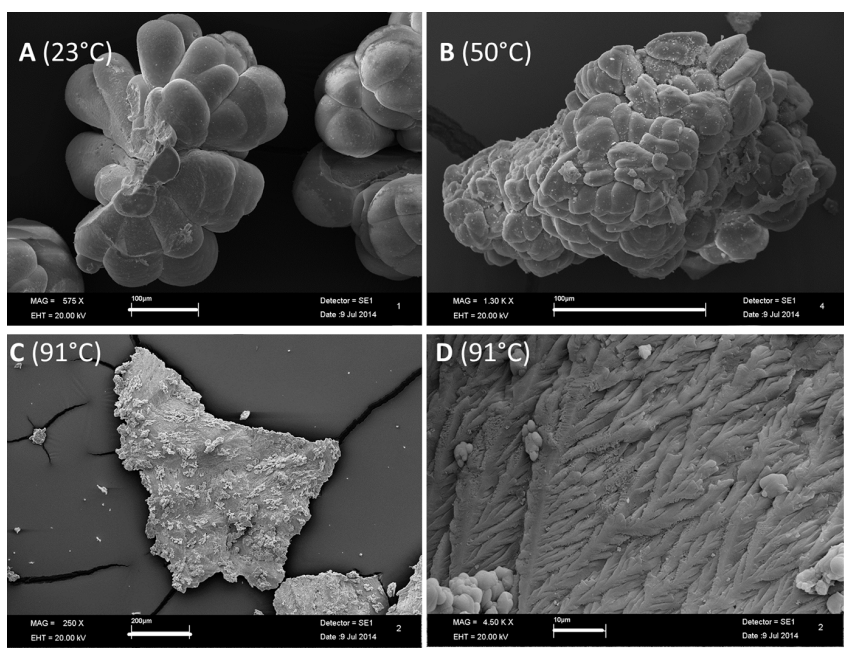

Figure 5. SEM images of vaterite aggregates in the order of increasing precipitation temperatures. Scale bars are $100 \mu \mathrm{m}$ in (a) and (b), $200 \mu \mathrm{m}$ in (c) and $10 \mu \mathrm{m}$ in (d). Samples NA-1 (a), NA-4 (b), and NA-9 (c and d) were used for imaging.

\subsection{XRD analysis}

The carbonate samples were analysed at the National History Museum, London, using an Enraf Nonius FR 590 powder diffractometer with $\mathrm{Cu}-\mathrm{K} \alpha$ radiation $(40 \mathrm{kV}, 35 \mathrm{~mA})$. In brief, the sample powder was placed in a thin layer on a sapphire substrate and measured by fixed beam-sample-detector geometry. Analysis times were adjusted to the counting statistics and varied between 10 and $90 \mathrm{~min}$. Signals and phase fractions were evaluated by comparing measured spectra with a mineral database using the program X'Pert Highscore (PANalytical B.V., 2009). Peak positions were calibrated with two standards (silver behenate and quartz). For phase quantification, a pure calcite standard and an aragonite standard were additionally measured.

For most samples, the dominant XRD peaks were found at $20.98( \pm 0.04)$, 24.86 $( \pm 0.02), 27.03( \pm 0.03), 32.74( \pm 0.03)$, $43.79( \pm 0.09)$, and $50.0( \pm 0.04)^{\circ}(2 \theta$, Fig. 7). In contrast, the characteristic and dominant calcite peak of the calcite standard is observed at $29.46^{\circ}$; those of the aragonite calibration standard are at 26.36, 27.35, 33.25 and $46.01^{\circ}$ ( $2 \theta$, Fig. 8). The aragonite peaks at 26.36 and $27.35^{\circ}$ were resolved for the pure aragonite standard, but the peak at $27.35^{\circ}$ overlapped with the vaterite peak at $\sim 27.03^{\circ}$ for aragonite-vaterite mixtures. Our laboratory $\mathrm{CaCO}_{3}$ samples are clearly different from aragonite and calcite, but coincide with the XRD data and d-spacing of vaterite. KabalahAmitai et al. (2013) measured vaterite d-spacing of 2.07 and $3.63 \AA$, corresponding to 43.69 and $24.50^{\circ}(2 \theta$ at $\mathrm{Cu}-\mathrm{K} \alpha$ radiation). Earlier work of Dupont et al. (1997) determined similar d-spacing values of 4.254, 3.591, 3.307, 2.741, 2.07 and $1.826 \AA$, corresponding to $20.86,24.77,26.94,32.64,43.69$ and $49.90^{\circ}$ ( $2 \theta$ at $\mathrm{Cu}-\mathrm{K} \alpha$ radiation). Our own results are 


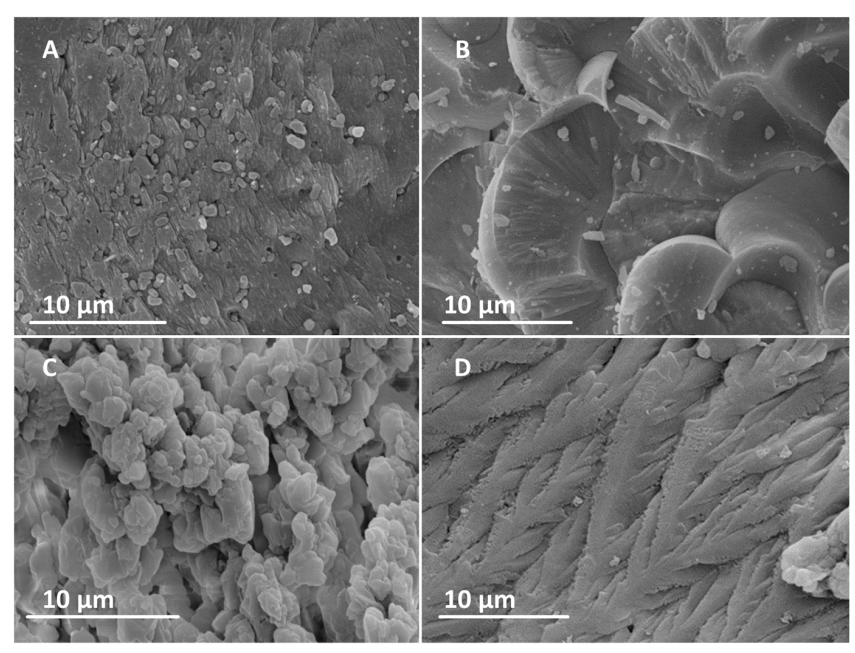

Figure 6. High-resolution SEM images of vaterite aggregates showing the internal structure in the order of increasing precipitation temperatures $\left(\mathbf{a}, 23 ; \mathbf{b}, 50 ; \mathbf{c}\right.$ and $\left.\mathbf{d}, 91^{\circ} \mathrm{C}\right)$. Two different growth structures are observed at $91{ }^{\circ} \mathrm{C}$ : aggregation of $\mu \mathrm{m}$-sized flat crystallites (c) and tree-like branching growth resulting in flat platelets (d).

close to these values confirming the precipitates to be composed of vaterite. In the case of the $37^{\circ} \mathrm{C}$ experiment, calcite is additionally present as a minor phase (about $5 \%$, visible in the peak at $29.46^{\circ}$, Fig. 7), whereas only traces of calcite are found in the $91^{\circ} \mathrm{C}$ experiment. An exact quantification of this small calcite fraction was not possible due to a general uncertainty of about $3 \%$ in the phase quantification. Half of the mineral phase at $80^{\circ} \mathrm{C}$ consists of calcite, whereas the other half is made up of equal proportions of aragonite and vaterite (Table 2, Fig. 8). Aragonite is also a minor phase in the $91^{\circ} \mathrm{C}$ experiment (6\%, Fig. 7).

\subsection{Isotope analysis}

Oxygen, carbon and clumped isotopes were analysed at the Qatar Stable Isotope Laboratory at Imperial College. Details of the sample preparation and mass spectrometric procedures are given in Kluge et al. (2015). In brief, per analysis $\sim 5 \mathrm{mg}$ sample was dissolved in orthophosphoric acid at $70^{\circ} \mathrm{C}$ to produce $\mathrm{CO}_{2}$ for the mass spectrometric measurement. The $\mathrm{CO}_{2}$ is cleaned manually, comprising a step for cryogenic water separation and one for contaminant removal via porous polymers (Porapak ${ }^{\mathrm{TM}} \mathrm{Q}$ ). Analyses were done using two dual-inlet isotope ratio mass spectrometers (Thermo Scientific MAT 253) that measure sample and reference gas alternately. Individual analyses have a precision of $0.2 \%$ for $\delta^{18} \mathrm{O}, 0.1 \%$ or $\delta^{13} \mathrm{C}$, and $0.03 \%$ for $\Delta_{47}$, based on replicate analyses of standards. Samples were measured repeatedly (typically three times) to reduce the uncertainty.

Carbonate $\delta^{18} \mathrm{O}$ values follow the trend determined by the temperature-dependent isotopic fractionation between water
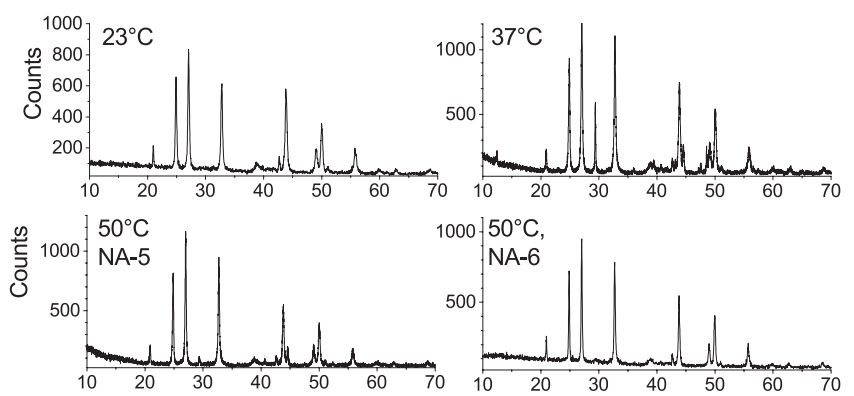

$1000-50^{\circ} \mathrm{C}$
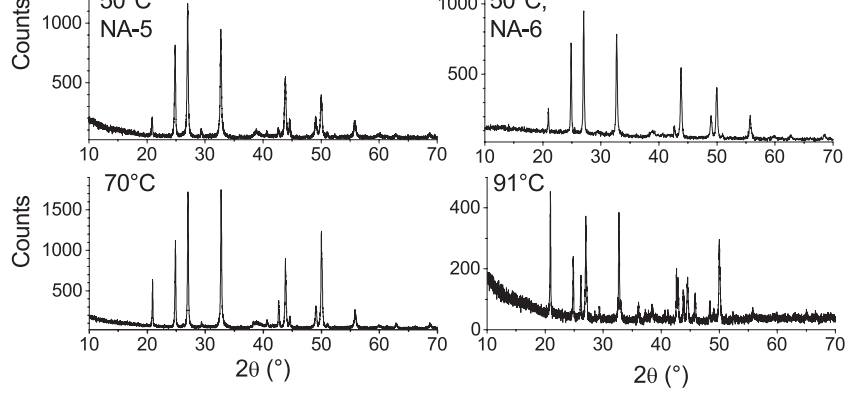

Figure 7. X-ray diffraction pattern of crystals from the laboratory experiments. The minerals that grew at $23^{\circ} \mathrm{C}$ show a pure vaterite signal. Similarly, minerals formed at 50 and $70^{\circ} \mathrm{C}$ yield an almost pure vaterite signal with a non-quantifiable fraction of calcite (traces, $\leq$ few \%). The samples at 37 and $91{ }^{\circ} \mathrm{C}$ contain a minor fraction of calcite and aragonite $(\leq 6 \%$ in total).

and calcite (Fig. 9). For calculation of the expected carbonate $\delta^{18} \mathrm{O}$ values, we used the fractionation factors of Kim and O'Neil (1997) and a water value of $-6.4 \pm 0.7 \%$ o $(-7.8 \pm 0.5 \%$ or the later repeat experiments NA-4 and NA-6). The water $\delta^{18} \mathrm{O}$ value was not directly measured but is based on back-calculation of aragonite and calcite samples that were precipitated in close temporal connection (within 3-12 days) of the vaterite experiments using the same water source and the same precipitation technique (see Kluge et al., 2015). The back-calculated water values from the pure $\mathrm{Ca}\left(\mathrm{HCO}_{3}\right)_{2}$ solution, used as a reference, correspond to the observed range of surface and ground water values of the London metropolitan area (Darling, 2003). For all experiments, the water was taken from the local water supply. Although we have a defined water reference value based on the pure $\mathrm{Ca}\left(\mathrm{HCO}_{3}\right)_{2}$ solution, we cannot exclude short-term fluctuations of the tap water $\delta^{18} \mathrm{O}$. However, it is unlikely that it exceeds the observed long-term variability of $\pm 0.7 \%$ (June-October 2012) and $\pm 0.5 \%$ (March-April 2013) for the back-calculated solution $\delta^{18} \mathrm{O}$ value.

The $\delta^{13} \mathrm{C}$ values vary between -18 and $-26 \%$ and reflect the negative signature of the $\mathrm{CO}_{2}$ tank gas used during the equilibration phase (Table 2). The $\delta^{13} \mathrm{C}$ values do not show a temperature dependence. Clumped isotope $\Delta_{47}$ values of vaterite samples decrease with increasing temperature and are similar to calcite or aragonite-calcite mixtures precipitated at the same temperature (Fig. 10). $\Delta_{47}$ values of calcite and calcite-aragonite mixtures were taken from Kluge et al. (2015) for comparison. 


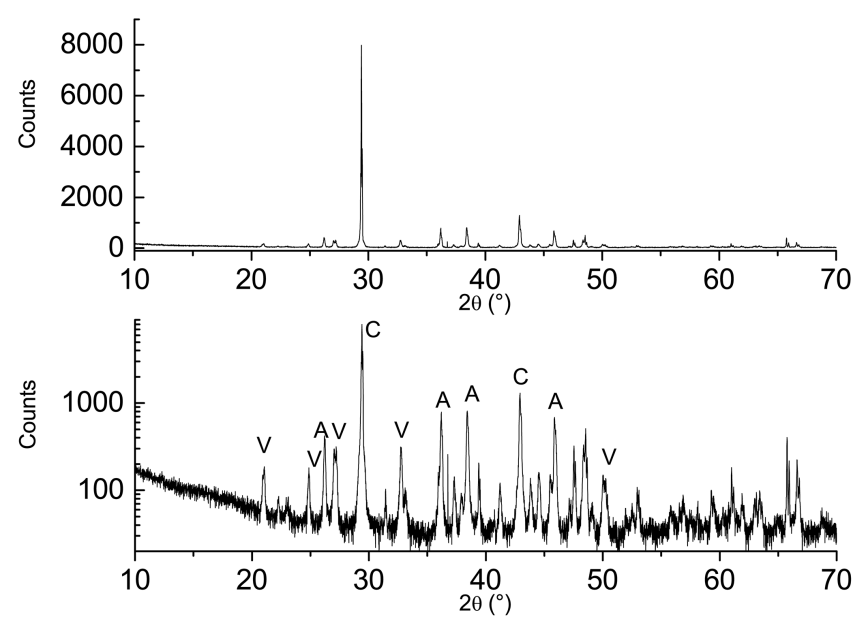

Figure 8. X-ray diffraction pattern of crystals from laboratory experiments. The experiment at $80^{\circ} \mathrm{C}$ produced a mixture of calcite, aragonite and vaterite (lower panel). For comparison, the XRD pattern of pure calcite is shown (upper panel). This example shows calcite that precipitated at $25^{\circ} \mathrm{C}$ from a pure $\mathrm{CaCO}_{3}$ supersaturated solution without $\mathrm{NaCl}$ addition. The peaks in the lower panel are labelled according to the related mineral structure (A: aragonite; $\mathrm{C}$ : calcite; V: vaterite).

\section{Discussion}

Vaterite was obtained over the entire experimental temperature range of $23-91{ }^{\circ} \mathrm{C}$. It is detected either as the only phase $\left(23,50,70^{\circ} \mathrm{C}\right)$ or as the major phase $(\geq 94 \%)$ with minor contributions from calcite or aragonite $\left(37,91^{\circ} \mathrm{C}\right)$. An exception is the experiment at $80^{\circ} \mathrm{C}$ where all anhydrous $\mathrm{CaCO}_{3}$ polymorphs were precipitated simultaneously. On average $80 \mathrm{mg}$ of vaterite was formed per experiment. This amount may be increased by longer experiment runs or by up-scaling of the setup using larger beakers with the same solution concentrations. A longer experiment duration appears to be the most effective approach. Considering the experiments from 23 to $70^{\circ} \mathrm{C}$ only, the yield increases exponentially with the duration, reaching a recovery rate (relative to the initially dissolved $\mathrm{CaCO}_{3}$ ) of $70 \%$ after $\sim 570 \mathrm{~h}$ (Fig. 11). An extrapolation of this trend is not easily possible as the precipitation rate will eventually decrease due to the continuously decreasing supersaturation. Another option of increasing the $\mathrm{CaCO}_{3}$ supersaturation in the initial solution was not tested, but has to be treated carefully. A higher initial chemical potential may produce a higher yield but also lead to the precipitation of other forms of $\mathrm{CaCO}_{3}$ such as ikaite (calcium carbonate hexahydrate, $\mathrm{CaCO}_{3}\left(\mathrm{H}_{2} \mathrm{O}\right)_{6}$ ) or amorphous calcium carbonate (Kawano et al., 2009).

This study shows that vaterite precipitation is not limited to a certain temperature range, e.g. to room temperature or from 10 to $48^{\circ} \mathrm{C}$ (Gussone et al., 2011), but can be performed at least up to $91^{\circ} \mathrm{C}$. A pressurized reaction vessel that prevents boiling of the solution could be used to extend vaterite

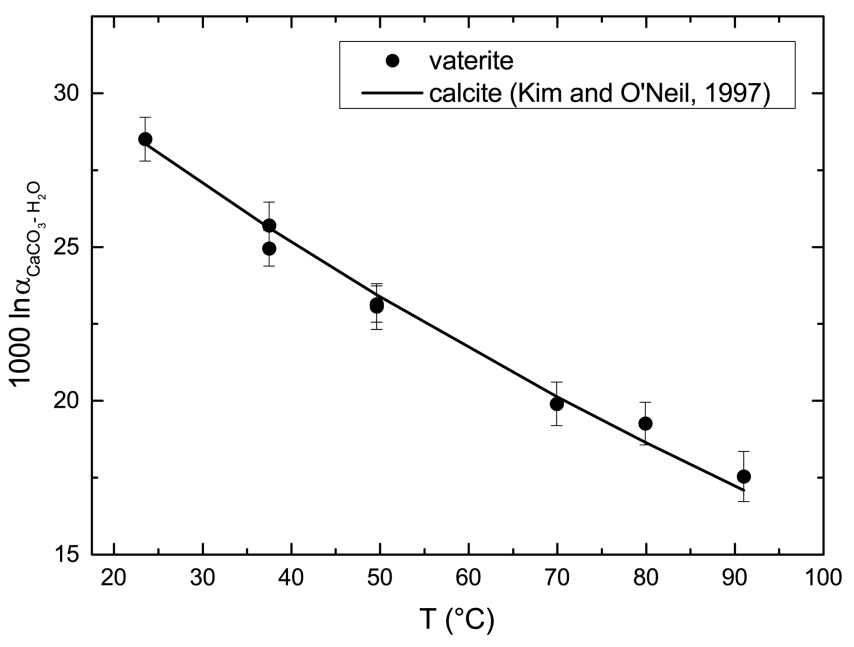

Figure 9. Oxygen isotope fractionation factor $1000 \ln \alpha\left(\mathrm{CaCO}_{3}-\right.$ $\mathrm{H}_{2} \mathrm{O}$ ) of vaterite (circles) relative to expected values for calcite (Kim and O'Neil, 1997; solid line). The sample at $80^{\circ} \mathrm{C}$ consists of a mixture of calcite, aragonite and vaterite. At 37 and $50^{\circ} \mathrm{C}$ repeat experiments were performed yielding fractionation factors in agreement with the previous experiment at the same temperature.

mineral formation to much higher temperatures (e.g. Kluge et al., 2015). A thermally and isotopically equilibrated $\mathrm{CaCO}_{3}$ supersaturated solution could be injected into the thermally equilibrated and saturated $\mathrm{NaCl}$ solution of a pressurized reaction vessel.

The detection of vaterite minerals over the large temperature interval of this study and its predominating character is surprising, given that many other studies emphasized the low stability of vaterite (e.g. McConnel, 1959). McConnel (1959) states that vaterite dissolves at room temperature at contact with water. However, our precipitates were air-dried at room temperature on Whatman ${ }^{\circledR}$ filter paper and stayed wet for a few hours, but did not transform into calcite. Furthermore, vaterite minerals were stored between several weeks and a year before being analysed by XRD and SEM. Despite long storage periods vaterite did not transform into other $\mathrm{CaCO}_{3}$ polymorphs; this implies that vaterite can be precipitated and stored for periods that are long enough to enable precise and detailed experimental analyses. Independent evidence for the stability of vaterite over years comes from biogenic samples such as bivalves, mollusks and other marine organisms (Lowenstamm and Abbott, 1975; Spann et al., 2010; Nehrke et al., 2012).

\section{Isotopic analysis of vaterite}

Our study presents a well-defined method for the isotopic study of vaterite. The technique for vaterite precipitation was modified from the procedures of McCrea (1950), O'Neil et al. (1969) and Kim and O'Neil (1997) that were developed for isotopic studies on calcite and aragonite minerals. The 


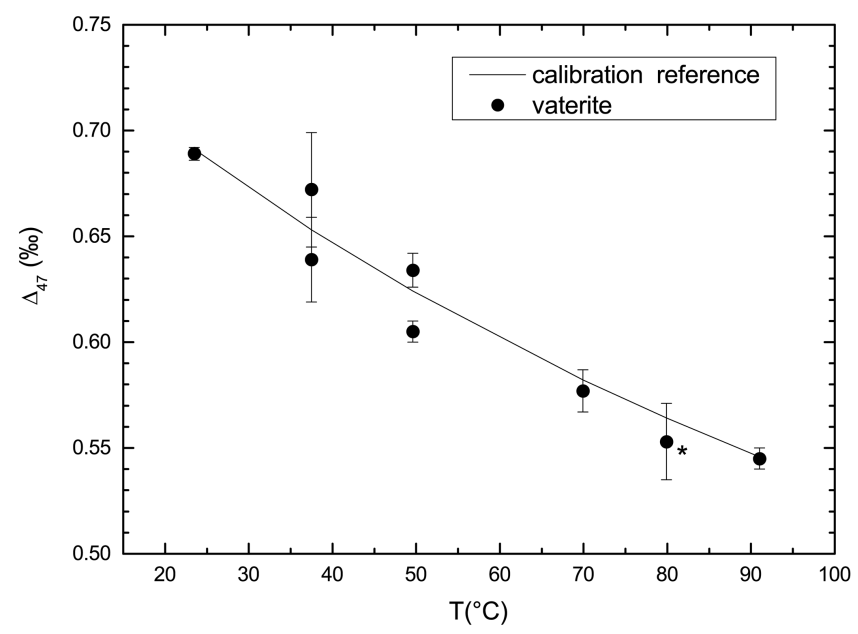

Figure 10. Measured $\Delta_{47}$ values of vaterite (circles) relative to expected values following the calibration line of Kluge et al. (2015). The sample at $80^{\circ} \mathrm{C}$ (marked by an asterisk) consists of a mixture of calcite, aragonite and vaterite. The calibration line of Kluge et al. (2015) was mainly determined on calcite.

values of Kim and O'Neil (1997) are commonly used as a reference for the oxygen isotope fractionation between calcite and water. Furthermore, for the temperature calibration of clumped isotopes, an analogous method was applied to precipitate calcite (Ghosh et al., 2006; Zaarur et al., 2013). The closeness of the methodology for synthetic vaterite and calcite precipitation ensures good comparability of the obtained results with widely used calibration and fractionation data.

The long equilibration procedure used in our experimental approach (Table 1) enables isotopic equilibration between the dissolved inorganic carbon (DIC) and water and among the DIC species. A $99 \%$ equilibrium between oxygen isotopes in water and DIC takes about $9 \mathrm{~h}$ at $25^{\circ} \mathrm{C}$ and a pH of $\sim 8$, whereas it is less than $2 \mathrm{~h}$ at temperatures above $40^{\circ} \mathrm{C}$ (Beck et al., 2005). For comparison, the equilibration duration was $23 \mathrm{~h}$ at $23^{\circ} \mathrm{C}, 14-21 \mathrm{~h}$ at $37.5^{\circ} \mathrm{C}$, and $3-17 \mathrm{~h}$ above $40^{\circ} \mathrm{C}$ (Table 1 ). This provides the necessary basis for a meaningful isotopic analysis of the precipitated vaterite which has not been attempted in a systematic manner so far.

Beyond the isotopic equilibration of the DIC with water, the precipitation rate and the ionic concentration of the solutions can affect isotope values. The growth rate has to be considered in the interpretation of isotope values as differences can be substantial between slow and rapidly grown minerals (up to $2 \%$ for $\delta^{18} \mathrm{O}$; Coplen, 2007; Dietzel et al., 2009; Gabitov et al., 2012). The growth rate in our study was not precisely monitored, but can be estimated from the derivative of the general relationship between experiment duration and mineral yield (Fig. 11). The mineral growth for temperatures below $80^{\circ} \mathrm{C}$ started very slowly with a value of $\sim 1.4 \times 10^{-10} \mathrm{~mol} \mathrm{~s}^{-1}$ and increased exponentially

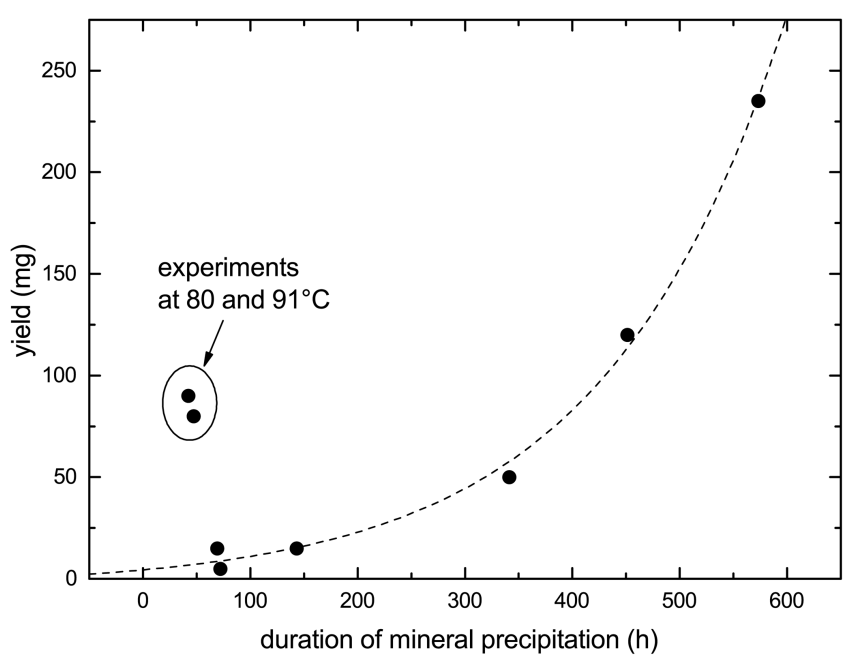

Figure 11. $\mathrm{CaCO}_{3}$ formed per experiment vs. duration. The initially dissolved $\mathrm{CaCO}_{3}$ amount was identical in all experiments (about $370 \mathrm{mg}$ ). The yield of experiments conducted below $80^{\circ} \mathrm{C}$ follows an exponential relationship with duration.

(e.g. to $1.1 \times 10^{-9} \mathrm{~mol} \mathrm{~s}^{-1}$ after $350 \mathrm{~h}$ ). Converting it relative to the growth surface (using the walls of the Erlenmeyer flask as a first-order estimate), the growth rate was about $3.7 \times 10^{-9} \mathrm{~mol}\left(\mathrm{~m}^{2} \mathrm{~s}\right)^{-1}$ at the beginning of the mineral formation and increased to $2.9 \times 10^{-8} \mathrm{~mol}\left(\mathrm{~m}^{2} \mathrm{~s}\right)^{-1}$ at $350 \mathrm{~h}$. These values only give an impression of the order of magnitude due to the limitation of the assumptions, but already demonstrate that the mineral formation was unlikely affected by rapid growth disequilibrium that is typically encountered at values above $10^{-7}-10^{-8} \mathrm{~mol}\left(\mathrm{~m}^{2} \mathrm{~s}\right)^{-1}$ (compare with, for example, Watkins et al., 2013). In contrast, in other vaterite precipitation techniques, two solutions were mixed, leading to almost instantaneous precipitation (e.g. Nebel and Epple, 2008). As rapid mineral growth may induce disequilibrium fractionation related to a mineral surface effect (Watson, 2004; Dietzel et al., 2009; Watson and Müller, 2009; DePaolo, 2011; Reynard et al., 2011; Gabitov et al., 2012; Gabitov, 2013), experiments with quasi-instantaneous mineral growth are not suitable for isotope studies. Consequently, we neither rapidly grew vaterite nor conducted isotope measurements on potentially fast growth phases.

Traditionally, vaterite was synthesized from mixtures of $\mathrm{CaCl}_{2}, \mathrm{~K}_{2} \mathrm{CO}_{3}$ (Kamhi, 1963) and admixtures of calgon (McConnell, 1960), or included other surfactants (Mori et al., 2009). In other experiments, a $\mathrm{CaCO}_{3}$ supersaturated solution was treated with surfactants (Dupont et al., 1997) or polymeric substances (Kirboga and Oner, 2013). In a few experiments, $\mathrm{Na}_{2} \mathrm{CO}_{3}$ replaced $\mathrm{K}_{2} \mathrm{CO}_{3}$ as the solution containing the carbonate ion (Nebel and Epple, 2008). The use of $\mathrm{CaCl}_{2}$ and especially $\mathrm{K}_{2} \mathrm{CO}_{3}$ could impact on the isotopic values of the forming minerals via preferential fractionation related to the hydration sphere of the $\mathrm{Ca}^{2+}$ and $\mathrm{K}^{+}$ions (Taube, 1954; Sofer and Gat, 1972; O'Neil and Truesdell, 
1991) and thus should either be restricted to low concentrations or avoided. Our method uses only $\mathrm{NaCl}$ as an additive that has been confirmed not to affect the isotope values of the DIC (e.g. O'Neil and Truesdell, 1991).

Before discussing the measured vaterite $\delta^{18} \mathrm{O}$ values and its implication for the oxygen isotope fractionation factor $\alpha_{\mathrm{CaCO}_{3}-\mathrm{H}_{2} \mathrm{O}}$, we note that we did not analyse the oxygen isotope composition of the solution per se. However, as the solution water is ultimately taken from the local water supply that reflects the London Metropolitan ground- and surface water $\delta^{18} \mathrm{O}$ of -6 to $-8 \%$ (Darling, 2003) and which is crossexamined using values from independent $\mathrm{NaCl}$-free experiments carried out in parallel, we have a defined reference water $\delta^{18} \mathrm{O}$ value $(-6.4 \pm 0.7,-7.8 \pm 0.5 \%$ or for the later repeat experiments NA-4 and NA-6; see Sect. 3.3). Thus, our results give a first-order guideline with respect to the temper-

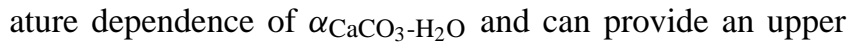
limit for the deviation of the fractionation factor of vaterite compared to aragonite and calcite. We compare our values to data of Kim and O'Neil (1997) due to similar experimental procedures and their universal use. Note that the exact value of the equilibrium oxygen isotope fractionation factor for calcite is under debate (Coplen, 2007; Dietzel et al., 2009; Gabitov et al., 2012; Kluge et al., 2014).

The fractionation $1000 \ln \alpha_{\left(\mathrm{CaCO}_{3}-\mathrm{H}_{2} \mathrm{O}\right)}$ of vaterite closely follows the values of Kim and O'Neil (1997) for calcite (Fig. 9). Over the entire experimental temperature range, vaterite values agree with the calcite values within uncertainty. Repeat experiments at 37 and $50^{\circ} \mathrm{C}$ confirm the initial results by providing almost identical fractionation factors. The average deviation is $0.0 \pm 0.4 \%$ and thus the vaterite oxygen isotope fractionation factor $\alpha_{\mathrm{CaCO}_{3}-\mathrm{H}_{2} \mathrm{O}}$ cannot be distinguished from that of calcite. Tarutani et al. (1969) observed vaterite to be enriched in ${ }^{18} \mathrm{O}$ by $0.5 \%$ relative to calcite at $25^{\circ} \mathrm{C}$. Kim and O'Neil (1997) detected a similar difference of $0.6 \%$ at 25 and $40^{\circ} \mathrm{C}$. Taking into account the measurement uncertainties, our experiments are consistent with both studies, which indicate a small or negligible difference of the fractionation $\alpha_{\mathrm{CaCO}_{3}-\mathrm{H}_{2} \mathrm{O}}$ between vaterite and calcite. Our study additionally constrains this value over the larger temperature range from 23 to $91^{\circ} \mathrm{C}$.

Carbonate clumped isotope $\Delta_{47}$ values are only determined by the mineral formation temperature at equilibrium conditions and are independent of the solution $\delta^{18} \mathrm{O}$ and $\delta^{13} \mathrm{C}$ values (for reviews see Eiler, 2007, 2011). We use the $\Delta_{47}$ $T$ calibration of Kluge et al. (2015) as a reference relationship as it was determined in the same laboratory, using the same preparation and measurement techniques ( $T$ in $K, \Delta_{47}$ in $\%$ ):

$$
\begin{aligned}
\Delta_{47}(T)= & 0.98 \times\left(-3.407 \times 10^{9} / T^{4}+2.365 \times 10^{7} / T^{3}\right. \\
& \left.-2.607 \times 10^{3} / T^{2}-5.880 / T\right)+0.293 .
\end{aligned}
$$

Equation (1) is given in the absolute reference frame of Dennis et al. (2011). Vaterite $\Delta_{47}$ values scatter around the $\Delta_{47}-T$ line of Eq. (1) with an average difference of $-0.003 \pm 0.013 \%$ and are thus indistinguishable from the calibration line (Fig. 10). Subtle differences in the mineral structure of the $\mathrm{CaCO}_{3}$ polymorph vaterite appear to be irrelevant for the ${ }^{13} \mathrm{C}-{ }^{18} \mathrm{O}$ clumping.

\section{Conclusions}

Vaterite was successfully synthesized from a $\mathrm{NaCl}$-saturated $\mathrm{CaCO}_{3}$ solution. Vaterite formed between 23 and $91^{\circ} \mathrm{C}$ and was generally pure or the major phase. The precipitation technique allows thermal and isotopic equilibration of the oxygen and clumped isotopes in the solution. The precipitation technique fosters slow mineral formation, which enables a meaningful isotopic analysis of the precipitated vaterite. Recovered vaterite amounts of up to $235 \mathrm{mg}$ also permit the precise determination of the clumped isotope value at each experiment temperature, which requires a relatively large sample aliquot of $5 \mathrm{mg}$ per replicate measurement.

The oxygen isotope fractionation between water and the vaterite mineral agrees within uncertainty with calcite (average difference $0.0 \pm 0.4 \%$ ). Clumped isotope $\Delta_{47}$ values are indistinguishable from calibration data (difference of $-0.003 \pm 0.013 \%$ ). The presented precipitation technique for vaterite, in particular the possibility for thermal and isotopic equilibration, opens research opportunities for precise investigation of isotope ratios on this unexplored $\mathrm{CaCO}_{3}$ polymorph.

\section{Appendix A}

$\delta^{18} \mathrm{O}, \delta^{13} \mathrm{C}$ and $\Delta_{47}$ values of samples and calibration standards are provided in the supplementary data file, together with raw data and transfer functions.

\section{The Supplement related to this article is available online at doi:10.5194/bg-12-3289-2015-supplement.}

Acknowledgements. We gratefully acknowledge funding from the Qatar Carbonates and Carbon Storage Research Centre (QCCSRC), provided jointly by Qatar Petroleum, Shell, and Qatar Science \& Technology Park. We thank Simon Davis for technical support and the Carbonate Research group at Imperial for fruitful discussions. We thank Jens Najorka for technical assistance during XRD measurements at the National History Museum London and for discussion of the results, and Alexander Varychev and Hans-Peter Meyer for SEM imaging. We are grateful for review comments by R. Gabitov and G. Nehrke which helped to improve the manuscript.

Edited by: J. Middelburg 


\section{References}

Beck, W. C., Grossman, E. L., and Morse, J. W.: Experimental studies of oxygen isotope fractionation in the carbonic acid system at $15^{\circ}, 25^{\circ}$ and $40^{\circ} \mathrm{C}$, Geochim. Cosmochim. Ac., 69, 3493-3503, 2005.

Coplen, T. B.: Calibration of the calcite-water oxygen-isotope geothermometer at Devils Hole, Nevada, a natural laboratory, Geochim. Cosmochim. Ac., 71, 3948-3957, 2007.

Darling, W. G.: Hydrological factors in the interpretation of stable isotopic proxy data present and past: a European perspective, Quat. Sci. Rev., 23, 743-770, 2003.

Davies, P., Dollimore, D., and Heal, G. R.: Polymorph transition kinetics by DTA, J. Therm. Anal., 13, 473-487, 1978.

Dennis, K. J., Affek, H. P., Passey, B. H., Schrag, D. P., and Eiler, J. W.: Defining an absolute reference frame for "clumped" isotope studies of $\mathrm{CO}_{2}$, Geochim. Cosmochim. Ac., 75, 7117-7131, 2011.

DePaolo, D. J.: Surface kinetic model for isotopic and trace element fractionation during precipitation of calcite from aqueous solutions, Geochim. Cosmochim. Ac., 75, 1039-1056, 2011.

Dietzel, M., Tang, J., Leis, A., and Köhler, S. J.: Oxygen isotopic fractionation during inorganic calcite precipitation - Effects of temperature, precipitation rate and $\mathrm{pH}$, Chem. Geol., 268, 107115, 2009.

Dupont, L., Portemer, F., and Figlarz, M.: Synthesis and study of well crystallized $\mathrm{CaCO}_{3}$ vaterite showing a new habitus, J. Mater. Chem., 7, 797-800, 1997.

Easton, A. J. and Claugher, D.: Variations in a growth form of synthetic vaterite, Mineral. Mag., 50, 332-336, 1986.

Eiler, J. M.: "Clumped-isotope" geochemistry-The study of naturally-occurring, multiply-substituted isotopologues, Earth Planet. Sci. Lett., 262, 309-327, 2007.

Eiler, J. M.: Paleoclimate reconstruction using carbonate clumped isotope thermometry, Quat. Sci. Rev., 30, 3575-3588, 2011.

Falini, G., Albeck, S., Weiner, S., and Addadi, L.: Control of aragonite or calcite polymorphism by mollusk shell macromolecules, Science, 271, 67-69, 1996.

Friedman, G. M. and Schultz, D. J.: Precipitation of vaterite $\left(\mathrm{CaCO}_{3}\right)$ during oil field drilling, Mineral. Mag., 58, 401-408, 1994.

Gabitov, R. I.: Growth-rate induced disequilibrium of oxygen isotopes in aragonite: An in situ study, Chem. Geol., 351, 268-275, 2013.

Gabitov, R. I., Watson, E. B., and Sadekov, A.: Oxygen isotope fractionation between calcite and fluid as a function of growth rate and temperature: An in-situ study, Chem. Geol., 306/307, 92$102,2012$.

Ghosh, P., Adkins, J., Affek, H. P., Balta, B., Guo, W., Schauble, E. A., Schrag, D., and Eiler, J. M.: ${ }^{13} \mathrm{C}-{ }^{18} \mathrm{O}$ bonds in carbonate minerals: A new kind of paleothermometer, Geochim. Cosmochim. Ac., 70, 1439-1456, 2006.

Gibson, R. E., Wyckoff, R. W. G., and Merwin, H. E.: Vaterite and $\mu$-calcium carbonate, Am. J. Sci., 10, 325-33, 1925.

Gussone, N., Nehrke, G., and Teichert, B. M. A.: Calcium isotope fractionation in ikaite and vaterite, Chem. Geol., 285, 194-202, 2011.

Han, Y., Hadiko, G., Fuji, M., and Takahashi, M.: Influence of initial $\mathrm{CaCl}_{2}$ concentration on the phase and morphology of $\mathrm{CaCO}_{3}$ prepared by carbonation, J. Mater. Sci., 41, 4663-4667, 2006.
Heide, F.: Über den Vaterit. Centralblatt für Mineralogie, Geol. Paläontol., 21, 641-651, 1924.

Hu, Q., Zhang, J., Teng, H., and Becker, U.: Growth process and crystallographic properties of ammonia-induced vaterite, Am. Mineral., 97, 1437-1445, 2012.

Jacob, D. E., Soldati, A. L-. Wirth, R., Huth, J., Wehrmeister, U., and Hofmeister, W.: Nanostructure, composition and mechanims of bivalve shell growth, Geochim. Cosmochim. Ac., 72, 54015415, 2008.

Johnston, J., Merwin, H. E., and Williamson, E. D.: The several forms of calcium carbonate, Am. J. Sci., 41, 473-512, 1916.

Kabalah-Amitai, L., Mayzel, B., Kauffmann, Y., Fitch, A. N., Bloch, L., Gilbert, P. U. P. A., and Pokroy, B.: Vaterite crystals contain two interspersed crystal structures, Science, 340, 454457, 2013.

Kamhi, S. R.: On the structure of Vaterite, $\mathrm{CaCO}_{3}$, Acta Cryst., 16, 770-772, 1963

Kawano, J., Shimobayashi, N., Miyake, A., and Kitamura, M.: Precipitation diagram of calcium carbonate polymorphs: its construction and significance, J. Phys., Condens. Matter, 21, 425102, doi:10.1088/0953-8984/21/42/425102, 2009

Kim, S. T. and O'Neil, J. R.: Equilibrium and nonequilibrium oxygen isotope effects in synthetic carbonates, Geochim. Cosmochim. Ac., 61, 3461-3475, 1997.

Kirboga, S. and Oner, M.: Effect of the experimental parameters on calcium carbonate precipitation, Chem. Engin. Trans., 32, 21192124, 2013.

Kluge, T., Affek, H. P., Dublyansky, Y., and Spötl, C.: Devils Hole paleotemperatures and implications for oxygen isotope equilibrium fractionation, Earth Planet. Sci. Lett., 400, 251-260, 2014.

Kluge, T., John, C. M., Jourdan, A.-L., Davis, S., and Crawshaw, J.: Laboratory calibration of the calcium carbonate clumped isotope thermometer in the $25-250^{\circ} \mathrm{C}$ temperature range, Geochim. Cosmochim. Ac., 157, 213-227, 2015.

Lowenstamm, H. A. and Abbott, D. P.: Vaterite: A mineralization product of the hard tissues of a marine organism (Ascidiacea), Science, 188, 363-365, 1975.

Mann, S. Heywood, B. R., Rajam, S., and Walker, J. B. A.: Structural and stereochemical relationships between Langmuir monolayers and calcium carbonate nucleation, J. Phys. D., 24, 154164, 1991.

Mayer, F. K. and Weineck, E.: Die Verbreitung des Kalziumkarbonates im Tierreich unter besonderer Berücksichtigung der Wirbellosen, Jenaische Zeitschrift für Naturwissenschaft, 66, 199-222, 1932.

McConnell, J. D. C.: Vaterite from Ballycraigy, Larne, Northern Ireland, Mineral. Mag., 32, 535-544, 1960.

McCrea, J. M.: On the isotopic chemistry of carbonates and a paleotemperature scale, J. Chem. Phys., 18, 849-857, 1950.

Meyer, H. J.: Struktur und Fehlordnung des Vaterits, Zeitschrift für Kristallographie, 128, 183-212, 1969.

Mori, Y., Enomae, T., and Isogai, A.: Preparation of pure vaterite by simple mechanical mixing of two aqueous salt solutions, Mater. Sci. Eng. C, 29, 1409-1414, 2009.

Nebel, H. and Epple, M.: Continuous preparation of calcite, aragonite and vaterite, and of magnesium-substituted amorphous calcium carbonate (Mg-Acc), Z. Anorg. Allg. Chem., 634, 1439$1443,2008$. 
Nehrke, G. and Van Cappellen, P.: Framboidal vaterite aggregates and their transformation into calcite: A morphological study, J. Crystal Growth, 287, 528-530, 2006.

Nehrke, G., Poigner, H., Wilhelms-Dick, D., Brey, T., and Abele, D.: Coexistence of three calcium carbonate polymorphs in the shell of the Antartic clam Laternula elliptica, Geochem. Geophy. Geos., 13, Q05014, doi:10.1029/2011GC003996, 2012.

O'Neil, J. R. and Truesdell, A. H.: Oxygen isotope fractionation studies of solute-water interaction, in: Stable isotope geochemistry: a tribute to Samuel Epstein, edited by: Taylor, H. P., O'Neil, J. R., and Kaplan, I. R., The Geochemical Society, Special Publication No.3, San Antonio, USA, 17-25, 1991.

O’Neil, J. R., Clayton, R. N., and Mayeda, T. K.: Oxygen isotope fractionation in divalent metal carbonates, J. Chem. Phys., 51, 5547-5558, 1969.

Pouget, E. M., Bomans, P. H., Goos, J. A. C. M., Frederik, P. M., With, G., and Sommerdijk, N. A. J. M.: The initial stages of template-controlled $\mathrm{CaCO}_{3}$ formation revealed by Cryo-TEM, Science, 323, 1455-1458, 2009.

Prien, E. L. and Frondel, C.: Studies of urolithiasis: I. The composition of urinary calculi, J. Urol., 57, 949-991, 1947.

Reynard, L. M., Day, C. C., and Henderson, G. M.: Large fractionation of calcium isotopes during cave-analogue calcium carbonate growth, Geochim. Cosmochim. Ac., 75, 3726-3740, 2011.

Rinne, F.: Röntgenographische Untersuchungen an einigen feinzerteilten Mineralien, Kunstprodukten und dichten Gesteinen, Zeitschrift für Kristallographie, 60, 55-69. 1924.

Sofer, Z. and Gat, J. R.: Activities and concentrations of oxygen-18 in concentrated aqueous salt solutions: analytical and geophysical implications, Earth Planet. Sci. Lett., 15, 232-238, 1972.

Spangenberg, K.: Die verschiedenen Modifikationen des Calciumcarbonates, Zeitschrift für Kristallographie, 56, 432-434, 1921.

Spann, N., Harper, E. M., and Aldridge, D. C.: The unusual mineral vaterite in shells of the freshwater bivalve Corbicula fluminea from the UK, Naturwissenschaften, 97, 743-751, 2010.
Sutor, D. J. and Wooley, S. E.: Gallstone of unusual composition: calcite, aragonite and vaterite, Science, 159, 1113-1114, 1968.

Tarutani, T., Clayton, R. N., and Mayeda, T. K.: The effect of polymorphism and magnesium substitution on oxygen isotope fractionation between calcium carbonate and water, Geochim. Cosmochim. Ac., 33, 987-996, 1969.

Taube, H: Use of oxygen isotope effects in the study of hydration of ions, J. Chem. Phys., 58, 523-528, 1954.

Vater, H.: Ueber den Einfluss der Lösungsgenossen auf die Krystallisation des Calciumcarbonates, Zeitschrift für Kristallographie und Mineralogie, 21, 433-490, 1893.

von Olshausen, S.: Strukturuntersuchungen nach der DebyeScherrer Methode, Zeitschrift für Kristallographie, 61, 463-514, 1924.

Wang, J. and Becker, U.: Structure and carbonate orientation of vaterite $\left(\mathrm{CaCO}_{3}\right)$, Am. Mineral., 94, 380-386, 2009.

Watkins, J. M., Nielsen, L. C., Ryerson, F. J., and DePaolo, D. J.: The influence of kinetics on the oxygen isotope composition of calcium carbonate, Earth Planet. Sci. Lett., 375, 349-360, 2013.

Watson, E. B.: A conceptual model for near-surface kinetic controls on the trace-element and stable isotope composition of abiogenic calcite crystals, Geochim. Cosmochim. Ac., 58, 14731488, 2004.

Watson, E. B. and Müller, T.: Non-equilbrium isotopic and elemental fractionation during diffusion-controlled crystal growth under static and dynamic conditions, Chem. Geol., 267, 111-124, 2009.

Xu, A.-W., Antonietti, M., Cölfen, H., and Fang, Y.-P.: Uniform hexagonal plates of vaterite $\mathrm{CaCO}_{3}$ mesocrystals formed by biomimetic mineralization, Adv. Funct. Matter, 16, 903-908, 2006.

Zaarur, S., Affek, H. P., and Brandon, M.: A revised calibration of the clumped isotope thermometer, Earth Planet. Sci. Lett., 382, 47-57, 2013. 